\title{
PULPING PROPERTIES OF KRAFT PULP OF NIGERIAN-GROWN KENAF (HIBISCUS CANNABINUS L.)
}

\author{
Jacob Smith Udohitinah ${ }^{\text {a }}$ and Abiodun Oluwafemi Oluwadare ${ }^{\mathrm{b}, *}$
}

This study was centered on finding a locally sourced alternative to imported long-fibre pulp for Nigerian pulp and paper mills. Fibre characteristics, chemical composition, and paper properties of pulp handsheets at different levels of kappa number and freeness in the range of $10{ }^{\circ} \mathrm{SR}$ and $62{ }^{\circ} \mathrm{SR}$ were evaluated using air-dried bast fibre obtained from decorticated kenaf plants grown in southern guinea savanna near Jebba, Nigeria. Kenaf bast fibre compared well with softwood, with an average fibre length of $2.90 \mathrm{~mm}$, a flexibility ratio of $57 \%$, and a Runkel ratio of 0.76 . Ash, lignin, and pentosan contents were $0.6 \%, 12.5 \%$, and $10.6 \%$, respectively, while the cellulose content was $55.5 \%$. Under alkali charge of 15.0 and, sulphidity of 17.5 with constant temperature, cooking time, and liquor-to-fibre ratio of $4.5: 1$, the screen yield was between 48.8 to $52.8 \%$ with kappa number 12.04 to 20.5 . Unbleached pulpsheets at kappa number between 15 and18.5 and pulp freeness $55^{\circ} \mathrm{SR}$ and bleached pulp freeness between 148 and $336 \mathrm{mLs}$ had better quality paper in terms of overall pulpsheet strength properties.

Keywords: Fibre characteristics; Chemical composition; Kraft Pulp; Screened yield; Pulp sheet properties; Hibiscus cannabinus

Contact information: a: Department of Chemical Engineering, Covenant University, Ota, Ogun State, Nigeria.; b: Department of Forest Resources Management, University of Ibadan, Box 9054, U.I. Post Office, Ibadan, Nigeria, Post code 200005*Corresponding author: femioluwadare@yahoo.com

\section{INTRODUCTION}

Activities of the paper, pulp, and board sub-sectors have long been regarded as main indicators of economic development of a country. The per capita paper consumption growth curves follow the general movement with gross national products, gross domestic product, and growth in literacy level of a nation (Diessen 1998). In line with the unique position of paper and pulp to the economic well being of a country, the federal government of Nigeria established three major paper mills namely; Nigerian Paper mills Limited, Jebba, Kwara State, Nigerian Newsprint Manufacturing Company, Oku-Iboku, Akwa-Ibom State, and Nigerian National Paper Manufacturing Company, Iwopin, Ogun State with total rated capacity of 265,000 metric tonnes (Osadare 1995). The original idea was to achieve self sufficiency in local demand for paper and paper products and to make Nigeria an exporter of pulp and paper products to the neighbouring countries. Given the unique ecological location of Nigeria with vast forest resources, the mills were designed to utilize mixtures of short fibre-hardwood species and imported long fibre pulp. While the short fibre pulp woods are found at the various ecological zones of Nigeria (Adeogun and Sotannde 2007), the huge investment on imported long 
fibre pulp has been a militating factor against the growth of the pulp and paper industry in the country (Osadare 1995; Aruofor 2000).

The climatic restriction to the establishment of sufficient long fibre pulpwood in Nigeria and the huge investment for importation of long fibre pulp has prompted researchers to explore whether fibres from non-wood species could be used for papermaking. Among the various non-woody plants that thrive well in Nigeria, Hibiscus cannabinus, commonly called kenaf, stands prominent.

Kenaf (Hibiscus cannabinus L.) is an annual crop in the family of Malvaceae that has been identified as a viable replacement for trees in the pulp and papermaking process. While the cultivation of kenaf is still in its infancy stage in Sub-Saharan Africa, kenaf is attracting much interest because of its apparent environmental and economic benefits (Nkaa et al. 2007; Balogun et al. 2009). It is a fast-growing plant that achieves a height of 5 to $6 \mathrm{~m}$ in about 4 to 5 months (Alexopoulou et al. 2000; Amaducci et al. 2000; Webber and Bledsoe 2002; Shukor et al. 2009). The increased commercial interest in using kenaf as a raw material for pulp and paper has led to the identification of its potential benefits (Osadare 1995; H'ng et al. 2009). Being a dicotyledon, kenaf has two distinct regions to its stem: outer bast (35 to 40\%) and inner woody core (60 to 65\%). Two major benefits identified to date are high yield and low lignin content. The low lignin content of kenaf is reflected in lower pulping chemical and energy consumption and lower bleaching requirements.

However, to use kenaf most effectively, it requires knowledge of not only the amounts of various substances that make up kenaf, but also how those substances contribute to the overall pulp and paper properties. The main focus of this study is to characterize the pulpsheet characteristics of kenaf grown in Nigeria relative to its fibre characteristics, chemical composition, and paper properties.

\section{EXPERIMENTAL}

\section{Fibre Dimensions Measurement}

The variety that was used in this study was the local variety from which a popular drink called 'Sobo' is made. The kenaf bast fibre was obtained by decorticating the woody plant of a 3-month-old kenaf plant. The woody core was separated from the bast fibre, which was used for the study. Essentially this study focused on the bast as a substitute for imported long fibre pulp in Nigeria. The bast ribbon was later baled and transported to the mill site for investigation. From the bast fibres obtained, samples were taken and macerated using the Franklin method (1945). To achieve this, the kenaf bast was cut into short lengths of about 10 to $15 \mathrm{~mm}$ and placed in a mixture of equal volume of 30\% hydrogen peroxide and 10\% glacial acetic acid in a test tube and boiled in a water bath until soft and bleached white. The slivers were then washed, and dispersed in a 30 $\mathrm{mL}$ test tube containing $20 \mathrm{~mL}$ of distilled water. The macerated fibres were later mounted on a slide and projected in a Reichert visopan microscope. The length $(L)$, diameter $(D)$, and lumen width $(d)$ of the projected fibres were measured on a visopan screen. The derived morphological indices, namely slenderness, flexibility, wall rigidity, and Runkel ratio were later calculated from the fibre characteristics. 


\section{Chemical Analysis}

The proportions of the chemical constituents in the kenaf bast fibres were determined based on approved standards of Technical Association of Pulp and Paper Industry (TAPPI). The alcohol-benzene extractive, ash, and 1\% alkali solubility of kenaf bast fibre were determined by TAPPI T12 os-75, T15 os-58, and T212 os-58, respectively. Similarly, the moisture content of the bast fibre, and the percentage of holocellulose, lignin, and pentosans were determined by TAPPI T12 os-75, T9m-54, T222 os-74, and T223 os-78, respectively. The percentage of alpha-cellulose, betacellulose, and gamma-cellulose were determined by TAPPI standard T203 os-74.

\section{Pulping Experiment}

Pulping was performed in a 25-litre electrically heated rotary laboratory digester at Federal Institute of Industrial Research, Lagos. For each cooking cycle, the liquor-tobast fibre ratio, cooking time, and cooking temperature were kept constant at 4.5:1, 90 minutes, and $170{ }^{\circ} \mathrm{C}$, respectively. Active alkali charge of $15 \%$ and sulphidity of $17.5 \%$ were used respectively. The cooking liquor was prepared in the laboratory at a ratio of 3:1 of sodium hydroxide to sodium sulphide. After each cook, a period of 20 minutes was allowed for gas down before the black liquor was ejected. All pulps were disintegrated, washed with cooled distilled water, and screened on a standard size $1 \mathrm{~mm} \times 1 \mathrm{~mm}$ netted sieve. The pulping conditions as shown below were chosen based on preliminary experiments:

Liquor-to-bast ratio

Active alkali as $\mathrm{Na}_{2} \mathrm{O}(\%)$

Sulphidity (\%)

Maximum temperature $\left({ }^{\circ} \mathrm{C}\right)$

Time to maximum temperature (min)

Time at maximum temperature (min)

\section{$4.5: 1$}

15.0

17.5

170

30

90

\section{Pulp Analysis}

Pulp yield expressed as percentage of the oven dry weight of the chips was determined together with the rejects proportion. Kappa number measurement was determined as specified in the laboratory tests manual of Iwopin Pulp and Paper Company. The freeness of the unbleached pulp was tested using a Schopper Riegler Freeness tester, being the only freeness tester available in the kraft pulp mill at Jebba according to the guildelines in the laboratory manual. It was expressed as the rate at which water drained from a suspension of $3 \mathrm{~g}$ of pulp in 1 litre of water. The freeness was carried out between $10{ }^{\circ} \mathrm{SR}$ and $62{ }^{\circ} \mathrm{SR}$, depending on the kappa number of the pulp.

\section{Handsheet Preparation and Testing}

The unbleached pulp was beaten in a PFI mill according to (TAPPI 1988). All the handsheets made at various level of beating and freeness were tested for burst, tear, breaking length, and stretch. 


\section{Pulp Bleaching}

Bleaching was carried out in order to evaluate the possible utilization of bleached pulp of kenaf for tissue and bond paper production. The bleaching was done using $30 \% /$ vol. of hydrogen peroxide $(\mathrm{P})$ in a vessel at $60^{\circ} \mathrm{C}$ for 1 hour followed by alkali extraction (E) using sodium hydroxide at $80^{\circ} \mathrm{C}$. The laboratory was not equipped to carry out other expected experiments including viscosity and burst. The freeness tester used was a Canadian Standard Freeness tester.

\section{RESULTS AND DISCUSSION}

\section{Fibre Dimensions and their Morphological Indices}

The average fibre dimensions and their derived morphological indices are presented in Table 1. The fibre dimensions are among the most important indices for selecting a lignocellulosic fibre for pulp and paper making. The mean fibre length was $2.90 \mathrm{~mm}$ with fibre diameter of $28.16 \mu \mathrm{m}$, lumen width of $6.08 \mu \mathrm{m}$, and cell wall thickness of $11.04 \mu \mathrm{m}$. The average fibre length, diameter, lumen width, and cell-wall thickness of sample compared well with the fibre dimensions of kenaf varieties reported by H'ng et al. (2009) and Nkaa et al. (2007) and also were comparable to the range of 2.7 to $4.6 \mathrm{~mm}$ for softwood tracheids (Ates et al. 2008). The implication of this is that kenaf bast fibre could go a long way in alleviating the problems posed by a shortage of longfibre pulp to Nigerian Paper mills. Similarly, kenaf bast fibres have remarkable derived morphological indices. The average slenderness, flexibility, and Runkel ratio of 105, 57\% and 0.76 compared favourably with some softwood pulps (Ververis et al. 2004; Akgul and Tozlouglu 2009). Nkaa et al. (2007) reported that a low Runkel ratio of $<1$ and a high flexibility ratio above $50 \%$ but less than $60 \%$ are necessary in fibres for papermaking. Fibres having these characteristics readily collapse and produce good surface contact in addition to fibre-to-fibre bonding. Therefore, papers made from kenaf bast are expected to have increased mechanical strength and thus be suitable for writing, printing, wrapping, and packaging purposes (Ververis et al. 2004; Saikia et al. 1997).

Table 1. Fibre Characteristics and Morphological Indices of Hibiscus cannabinus Bast

\begin{tabular}{|c|c|}
\hline Fibre characteristics & Mean \\
\hline Fibre length $(\mathrm{mm})(L)$ & 2.9 \\
\hline Fibre diameter $(\mu \mathrm{m})(D)$ & 28.16 \\
\hline Lumen width $(\mu \mathrm{m})(d)$ & 11.04 \\
\hline Cell-wall thickness $(\mu \mathrm{m})(w)$ & $105: 1$ \\
\hline Slenderness $(L / D)$ & 57 \\
\hline Flexibility $(/ / D \times 100)(\%)$ & 0.76 \\
\hline Runkel ratio $(2 w / d)$ & $(w)$ \\
\hline
\end{tabular}




\section{Chemical Composition}

The chemical composition of a lignocellulosic plant gives an idea of how feasible the plant material is for papermaking. The results of the average chemical composition of kenaf bast fibre are presented in Table 2.

The mean values of alcohol-benzene extractives of $0.7 \%$ and $1 \%$ alkali solubility of $15.2 \%$ are low. This indicates possible low pitch deposition and low rate of biological degradation. Pitch problems are often associated with high-extractive trees like pine. Similarly, the low percentage of ash (0.6\%), lignin (12.5\%), and pentosans $(10.6 \%)$ in the kenaf bast is an indication that low amount of pulping liquor will be required to pulp the kenaf bast. Kristova et al. (1998) opined that high ash content will affect normal alkali consumption and give problems with waste liquor recovery. Ververis et al. (2004) also suggested that the presence of low percentages of lignin and ash indicates that milder pulping conditions (lower temperature and chemical charges) will be required to pulp kenaf compared to softwood and hardwoods.

Meanwhile, the cellulose content of the kenaf bast is high. The combination of cellulose and hemicellulose is called holocellulose. The results of the chemical analysis of Nigerian grown kenaf showed that holo-cellulose accounted for $73.2 \%$ of kenaf bast, while the alpha-cellulose accounted for $55.5 \%$ (Table 2). These values are quite high. According to Nieschlag et al. (1960) plant materials with alpha-cellulose of 34\% and above are characterised as promising for pulp and paper manufacture from a chemical composition point of view. It has been shown that cellulose and aplha-cellulose content can be correlated with yields of unbleached and bleached pulps respectively (Wood 1981). The amount of soluble cellulose, which includes beta-cellulose (14.8\%) and gamma-cellulose (2.9\%), also attests to the expected pulp yield of kenaf bast. However, the appreciable amount of beta-cellulose (14.8\%) also coroborated the fact that a milder pulping condition might be needed to pulp kenaf bast, as beta-cellulose constitutes the fraction of cellulose that might be degraded during pulp washing.

Table 2. Chemical Analysis of Hibiscus cannabinus Bast

\begin{tabular}{|c|c|}
\hline Properties & Bast \\
\hline Alcohol-Benzene (\%) & 0.7 \\
\hline 1\% alkali solubility (\%) & 15.2 \\
\hline Ash (\%) & 0.6 \\
\hline Lignin (\%) & 12.5 \\
\hline Pentosan (\%) & 10.6 \\
\hline Holocellulose (\%) & 73.2 \\
\hline Alpha-cellulose (\%) & 55.5 \\
\hline Beta-cellulose (\%) & 14.8 \\
\hline Gamma-cellulose (\%) & 2.9 \\
\hline
\end{tabular}

\section{Pulp Properties of Unbleached Kraft Pulp of Kenaf Bast}

The effect of pulping parameters, which include active alkali charge and sulphidity of the pulping liquor, on screen yield and kappa number of unbleached pulp is presented in Table 3. It could be observed that the average screen yield of the pulp was a bit higher at the specified sulphidity of $17.5 \%$ and active alkali of $15.0 \%$, respectively; 
however, the variation observed in kappa number may be attributed to some abnormality encountered during pulping operation (electricity failure). Denis et al. (2004) reported that the effect of alkali charge on pulp properties is more important than that of sulphidity. An increase in percentage of active alkali charge of pulping liquor could result in low pulp yield.

Meanwhile, kappa number is an indication of the bleachability of the pulp. It estimates the amount of chemicals required during bleaching of wood pulp to obtain a pulp with a given degree of brightness. Since the amount of bleach needed is related to the lignin content of the pulp, the kappa number can be used to monitor the effectiveness of the lignin-extraction phase of the pulping process (Biermann 1993). The highest pulp yield of $52.8 \%$ was attained when the kappa number was 18.5 at an active alkali charge of $15.0 \%$ and sulphidity of $17.5 \%$. When kappa number increased beyond a level, (in this case 18.5), the yield was equally low (Fig.1); it could be inferred that low kappa number is associated with low yield. (Table 3 ).

The results of the testing of physical properties of the unbleached pulp are presented in Table 4. The unbleached pulps were beaten in a PFI mill between 0 and 5000 revolutions, and handsheets were prepared for physical properties. The ${ }^{0} \mathrm{SR}$ value of the pulp increased insignificantly from the range 10-55 at a kappa number of 16.5 to the range 19-62 at a kappa number of 20.4 after 5000 PFI revolutions $(p<0.05)$. The ease of beating of the pulp can be explained by the milder pulping conditions required and the low lignin content of the pulp. Other strength properties were significantly affected. The breaking length $(4.71 \mathrm{Km})$ and burst factor $\left(46.47 \mathrm{kPa}-\mathrm{m}^{2} / \mathrm{g}\right)$ were highest when the pulp was beaten at a freeness level of 10 to $55^{\circ} \mathrm{SR}$ at a kappa number of 16.5. The tear factor was much higher than hardwood (Adeogun and Sotannde 2007). The tear factor of 298.4 $\mathrm{mN} . \mathrm{m}^{2} / \mathrm{g}$ was the highest in pulp with freeness level between 20-52 ${ }^{\circ} \mathrm{SR}$ and a kappa number of 20.5. The high fibre length and cell wall thickness of kenaf bast might be the reason for the high tear factor. Meanwhile, the relationships between pulp freeness strength properties at the optimum yield of the unbleached pulp of 52.8\% and kappa number of 18.5 are presented in Figs. 2 and 3. It was observed that at varying freeness level, the strength of the unbleached was greatly enhanced. All these show that kenaf bast has strength properties similar to softwood.

Table 3. Alkali Charge, Kappa Number and Screened Yield of Unbleached Kraft Pulp of Kenaf Bast*

\begin{tabular}{|c|c|c|c|c|}
\hline Cook number & $\begin{array}{c}\text { Active alkali } \\
\left(\% \mathrm{Na}_{2} \mathrm{O}\right)\end{array}$ & Sulphidity (\%) & Kappa number & Screen yield (\%) \\
\hline 1 & 15.0 & 17.5 & 16.5 & 51.5 \\
\hline 2 & 15.0 & 17.5 & 18.5 & 52.8 \\
\hline 3 & 15.0 & 17.5 & 14.8 & 50.8 \\
\hline 4 & 15.0 & 17.5 & 12.0 & 48.8 \\
\hline 5 & 15.0 & 17.5 & 20.5 & 51.2 \\
\hline 6 & 15.0 & 17.5 & 20.4 & 52.6 \\
\hline \multicolumn{4}{|l|}{ *Maximum temperature $\left(170^{\circ} \mathrm{C}\right)$; pulping time (90 minutes) } \\
\hline
\end{tabular}




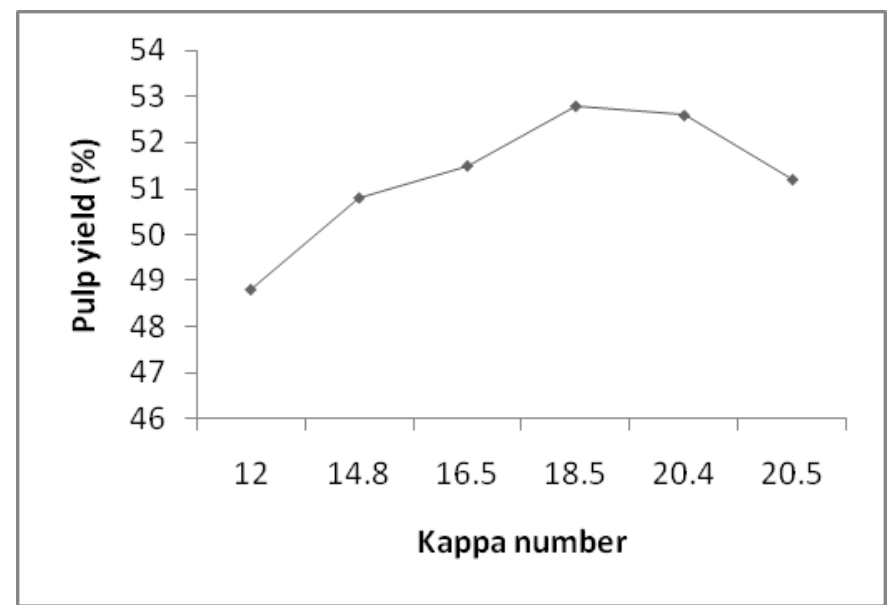

Fig. 1. Relationship between kappa number and screen yield of unbleached kraft Pulp of kenaf bast

Table 4. Properties of Unbleached Kenaf Bast Kraft Pulp Produced at Optimum Active Alkali and Sulphidity

\begin{tabular}{|c|c|c|c|c|c|c|}
\hline Cook No & 1 & 2 & 3 & 4 & 5 & 6 \\
\hline Kappa No & 16.5 & 18.5 & 14.8 & 12.04 & 20.5 & 20.4 \\
\hline \multicolumn{7}{|c|}{ Freeness ( $\left.{ }^{\circ} \mathrm{SR}\right)$} \\
\hline Range & $10-55$ & $15-55$ & $15-51$ & $18-56$ & $20-52$ & $19-62$ \\
\hline Mean & 29.6 & 34.2 & 31.8 & 36.6 & 38.0 & 39.6 \\
\hline \multicolumn{7}{|c|}{ Basis weight (g.s.m) } \\
\hline Range & $96-105$ & $100-110$ & $99-101$ & $99-103$ & $100-105$ & $98-106$ \\
\hline Mean & 100.4 & 103.4 & 100.0 & 101.2 & 102.0 & 101.0 \\
\hline \multicolumn{7}{|c|}{ Caliper (mm) } \\
\hline Range & $0.21-0.24$ & $0.20-0.39$ & $0.32-0.41$ & $0.35-0.45$ & $0.36-0.43$ & $0.32-0.42$ \\
\hline Mean & 0.22 & 0.26 & 0.36 & 0.40 & 0.39 & 0.37 \\
\hline \multicolumn{7}{|c|}{ Bulk $\left(\mathrm{cm}^{3} / \mathrm{g}\right)$} \\
\hline Range & $1.97-2.40$ & $2.00-3.67$ & $3.17-4.13$ & $4.05-4.95$ & $3.60-4.22$ & $3.26-4.24$ \\
\hline Mean & 2.17 & 2.48 & 3.58 & 4.28 & 3.84 & 3.62 \\
\hline \multicolumn{7}{|c|}{ Breaking length $(\mathrm{Km})$} \\
\hline Range & $3.74-5.66$ & $1.28-3.28$ & $2.51-4.46$ & $2.95-3.88$ & 2.16-3.99 & $2.84-3.40$ \\
\hline Mean & 4.71 & 2.68 & 3.44 & 3.44 & 3.04 & 3.17 \\
\hline \multicolumn{7}{|c|}{ Stretch (\%) } \\
\hline Range & $1.38-2.41$ & $1.47-2.43$ & $1.53-2.75$ & $1.23-2.61$ & $0.99-2.06$ & $1.52-1.98$ \\
\hline Mean & 1.93 & 2.00 & 1.83 & 1.91 & 1.68 & 1.75 \\
\hline \multicolumn{7}{|c|}{ Tear index $\left(\mathrm{mN} \cdot \mathrm{m}^{2} / \mathrm{g}\right)$} \\
\hline Range & $6.9-28.3$ & $16.0-35 . .2$ & $20.0-28.4$ & $19.4-26.2$ & 22.4-39.6 & 24.2-32.6 \\
\hline Mean & 14.46 & 24.86 & 23.90 & 22.38 & 29.84 & 27.04 \\
\hline \multicolumn{7}{|c|}{ Burst factor $\left(\mathrm{kPa} \cdot \mathrm{m}^{2} / \mathrm{g}\right)$} \\
\hline Range & $38.59-55.0$ & $26.19-43.70$ & $27.50-46.72$ & $27.07-38.74$ & $17.25-33.50$ & $21.34-30.56$ \\
\hline Mean & 46.47 & 37.09 & 35.33 & 33.02 & 26.69 & 25.38 \\
\hline
\end{tabular}




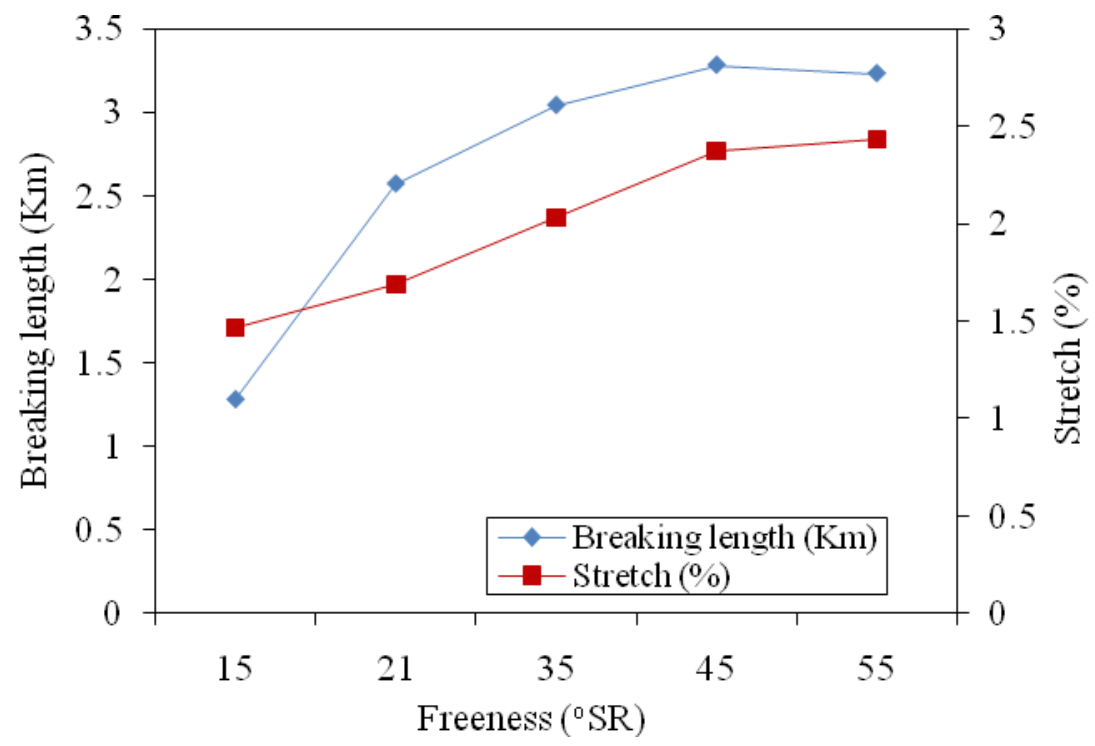

Fig. 2. Effect of freeness on breaking length and stretch of unbleached kraft pulp of kenaf bast

To evaluate the effect of beating on the bleached pulps obtained, the strength properties of bleached handsheets were determined at different degrees of beating. The physical strength properties of bleached pulp carried out in a laboratory valley with 0 , 1000, 2000, 3000, 4000, and 5000 revolutions is given in Table 5. The results indicate that bleached kraft pulp of kenaf bast gave an unbeaten freeness of $550 \mathrm{~mL}$, while the tear index, tensile strength, and stretch were $11.84 \mathrm{mN} . \mathrm{m}^{2} / \mathrm{g}, 2.09 \mathrm{~km}$, and $3.94 \%$, respectively. Similarly, the basis weight, drainage, and brightness of the unbeaten bleached pulp were 62 gsm, 4.98 seconds, and 61.2\%, respectively. But when the revolutions of beating were increased from 1000 to 5000, the freeness of the pulp decreased considerably (Table 5), giving substantial improvement in the physical strength properties of the bleached pulp. At a freeness of $148 \mathrm{~mL}$, tensile and stretch improved considerably while tear decreased. For example, while tensile strength and stretch increased from 3.30 to $4.80 \mathrm{kN} / \mathrm{m}$ and 3.74 to $4.39 \%$ respectively, tear index decreased from 10.00 to $6.40 \mathrm{mN} \mathrm{m}^{2} / \mathrm{g}$. This is expected, as less energy will be required to pull the fibre apart. This finding is in line with the results of Jahan et al. (2007) on Jute fibres and Nezamoleslami et al. (1997) on kenaf bast. Significant improvement in pulp brightness varied inconsistently from the unbeaten state to the final state, as shown in Table 5.

Table 5. Properties of Bleached Kraft Pulp of Kenaf Bast

\begin{tabular}{lllllll}
\hline Beating revolution & Unbeaten & 1000 & 2000 & 3000 & 4000 & 5000 \\
\hline CSF $(\mathrm{mL})$ & 550 & 508 & 405 & 336 & 189 & 148 \\
Basis weight (g.s.m) & 62 & 60 & 59 & 59 & 62 & 59 \\
Tear $\left(\mathrm{mN} \mathrm{m}^{2} / \mathrm{g}\right)$ & 11.84 & 10.00 & 7.20 & 6.89 & 6.60 & 6.40 \\
Tensile strength (kN/m) & 2.09 & 3.30 & 4.35 & 4.63 & 4.78 & 4.80 \\
Stretch (\%) & 3.94 & 3.74 & 3.81 & 3.86 & 4.18 & 4.39 \\
Drainage time (Secs) & 4.98 & 4.55 & 5.89 & 7.99 & 10.34 & 18.40 \\
Brightness (\%) & 58.0 & 58.6 & 58.8 & 61.2 & 59.7 & 59.6 \\
\hline
\end{tabular}




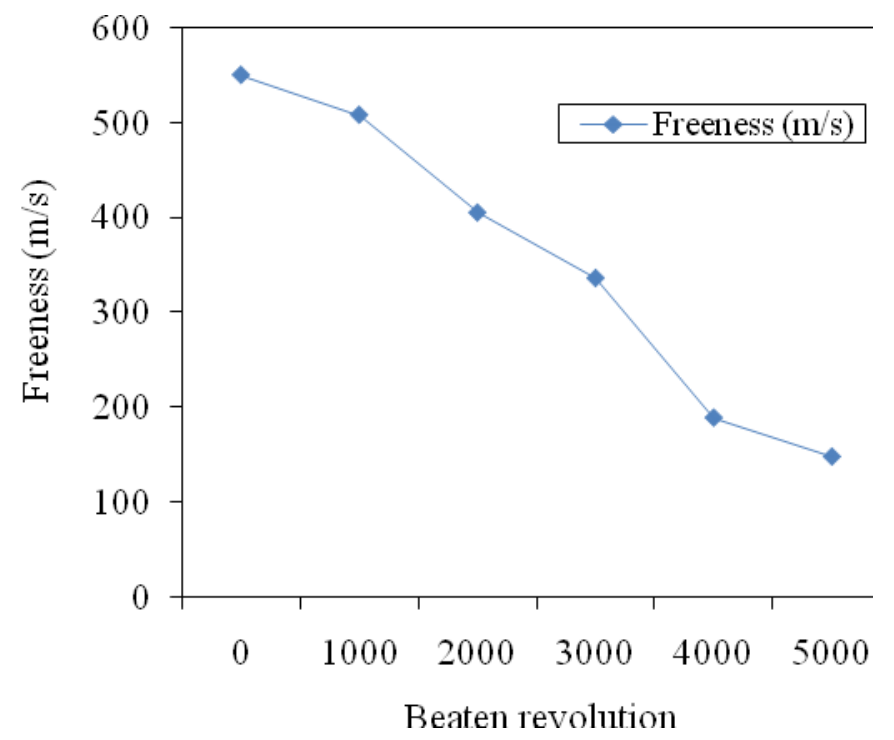

Fig. 3. Effect of beating revolution on freeness of bleached kraft pulp of kenaf bast

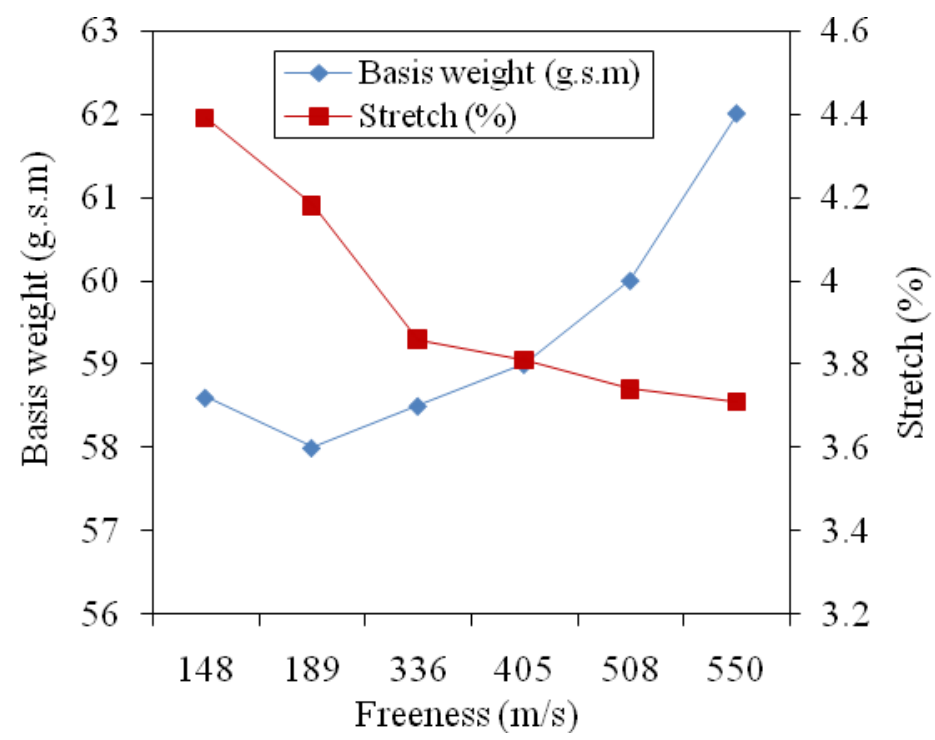

Figure 4. Relationship of pulp freeness with basis weight and stretch of bleached kraft pulp of kenaf bast

\section{CONCLUSIONS}

1. From the results of this experiment, it is obvious that kenaf bast can play a significant role in reducing the high cost associated with the importation of longfibre pulp to the pulp and paper mills in Nigeria.

2. The bast of Nigerian grown kenaf has great similarity with softwoods. The average fibre length, flexibility, and Runkel ratio were found to be $2.90 \mathrm{~mm}, 57 \%$, and 0.76, respectively, which shows that paper from kenaf bast can have mechanical strength similar to that of softwood. 
3. The low percentage of ash, lignin, and pentosans in the kenaf bast showed that milder pulping condition will be required to pulp kenaf bast compared to both softwoods and hardwoods. However, the high percentage of holocellulose and alpha cellulose corroborated the high screen yield of kenaf pulp, which stood at between 48.8 and $52.8 \%$ at a kappa number of 12.04 to 20.5 .

4. Analysis of the pulp properties showed that kenaf bast can be easily pulped using the kraft pulping method to a low kappa number with acceptable yield. The highest screen yield of $52.8 \%$ at a kappa number of 18.5 was quite remarkable.

5. The burst factor, tear index, breaking length (tensile strength), and stretch of kenaf bast showed much similarity to softwood pulp.

\section{ACKNOWLEDGMENTS}

The authors are grateful for the support of Raw Materials Research and Development Council, Abuja for the financial support and Nigerian Paper Mill, Jebba, for the use of their facilities.

\section{REFERENCES CITED}

Adeogun, P. F., and Sotannde, O. A., (2007). “Assessment of some savannah hardwood species for pulp and paper production,” Research Journal of Sciences 13(1-2), 67-71.

Akgul, M., and Tozlouglu, A. (2009). "Some chemical and morphological properties of juvenile woods from beech (Fagus orientalis L.) and pine (Pinus nigra A.) plantations,” Trends Applied Sci. Res. 4, 116-125.

Alexopoulou, E., Christou, M., Mardikis, M., and Chatzianthanassiou, A. (2000). "Growth and yields of kenaf varieties in central Greece,” Ind. Crops Prod. 11, 163-172.

Amaducci, S., Amaducci, M. T., Benati, R., and Venturi, G. (2000). "Crop yield and quality parameters of four annual fibre crops (hemp, kenaf, maize and sorgum) in the North of Italy,” Ind. Crops Prod. 11, 179-186.

Aruofor, R. O. (2000). "Review and improvement of data related to wood-products in Nigeria. An output of the EC-FAO Partnership Programme (1998-2000) - Project GCP/INT/679/EC, Data collection and Analysis for sustainable forest management in ACP Countries,” 16 pp.

Ates, S., Ni, Y. H., Akgul, M., and Tozloglu, A. (2008). “Characterization and evaluation of Paulownia elongate as a raw material for paper production,” African J. Biotechnol. 7, 4153-4158.

Balogun, M. O., Akande, S. R., Raji, J. A., Ogunbodede, B. A., Agbaje G. O., and Adeyeye, O. O. (2009). "Development of high yielding, late maturing kenaf (Hibiscus cannabinus) using gamma irradiation,” In: Induced Plant Mutations in the Genomics Era, Shu, Q. Y. (ed.), Food Agric. Org. United Nations, Rome, 395-396.

Biermann, C. J. (1993). Essentials of Pulping and Paper Making, Academic Press. San Diego, CA, USA, 472 pp. 
Diesen, M. (1998). “World paper markets,” In: Papermaking Science and Technology (ser.), Diesen, M. (ed.), Economics of the Pulp and Paper Industry, Vol. 1, Fapet Oy, Helsinki, Finland, pp. 61.

Deniz, I., Kirci, H., and Ates., S. (2004). "Optimization of wheat straw Triticum drum kraft pulping,” Ind. Crop Prod. 19, 237-243.

Franklin, G. L. (1945). "Preparation of thin selection of synthetic resins and wood-resins composite and new merceration method for wood," Nature 155, 51-55.

H’ng, P. S., Khor, B. N., Tadashi, N., Aini, A. S. N., and Paridah, M. T. (2009).

"Anatomical structures and fibre morphology of new kenaf varieties," Asian J. Sci. Resh. 2(3), 161-166.

Jahan, M. S., Al-Maruf, A., and Quaiyyum, M. A. (2007). "Comparative studies of pulping of jute fiber, jute cutting and jute caddis,” Bangladesh J. Sci. Ind. Res. 42(4), 425-434.

Khristova, P., Bentcheva, S., and Karar, L. (1998). ”Soda-AQ pulp blends from kenaf and sunflower stalks,” Biores. Technol. 66, 99-103.

Nezamoleslami, A., Suzuki, K., and Kadoya, T. (1997). "Preparation and properties of retted kenaf bast fiber pulp and evaluation as substitute for manila hemp pulp,” $J$. Pack. Sci. Technol. 6(6), 339-347.

Nieschlag, H. J., Nelson, G. H., Wolff, J. A., and Perdue, R. E. (1960). “A search for new fiber crops,” Tappi 43(3), 193.

Nkaa, F. A., Ogbonnaya, C. I., and Onyike, N. B. (2007). "Effect of differential irrigation on physical and histochemical properties of kenaf (Hibiscus cannabinus L.) grown in the field in Eastern Nigeria,” African J. Agric. Resh. 2(6), 252-260.

Osadare, A. O. (1995). "Strategies toward self-sufficiency in long fibre pulp production in Nigeria,” Nig. J. For. 24, 16-20.

Saikia, C. N., Goswami, T., and Ali, F. (1997). "Evaluation of pulp and paper making characteristics of certain fast growing plants,” Wood Sci. Technol. 31(6), 467- 475.

Shukor, N. A. A., Hamzah, M. B., Hamid, H. A., Salleh, G., and Nasir, M. F. (2009). "Growth and phenology of kenaf (Hibiscus cannabinus L.) varieties," Pertanika J. Trop. Agric. Sci. 32(1), 29-33.

Technical Association of Pulp and Paper Industry (TAPPI), (1985). "Freeness of pulp. Tappi T. 227 om-85, Technical Association of the Pulp and Paper Industry, Atlanta.

Technical Association of Pulp and Paper Industry (TAPPI), (1988). "Forming handsheets for physical tests of pulp,” TAPPI T 205 om-88, Technical Association of the Pulp and Paper Industry, Atlanta.

Ververis C., Georghiou, K., Christodoulakis, N., Santas, P., and Santas, R. (2004). "Fiber dimensions, lignin, and cellulose content of various plan materials and their suitability for paper production,” Ind. Crops Prod. 19, 245-254.

Webber, C. L., and Bledsoe, V. K. (2002). "Plant maturity and kenaf yield components," Ind. Crops Prod. 16, 81-88

Wood, I. M. (1981). "The utilization of field crops and crop residues for paper pulp production,” Field Crop Abstracts 34, 557-568.

Article submitted: July 26, 2010; Peer review completed: Sept. 3, 2010; Revised version received: Jan. 7, 2011; Accepted: Jan. 15, 2011; Published: Jan 18, 2011. 